\title{
Pendidik dalam Perspektif Al-Quran dan Pendidikan Islam
}

\author{
Juarman $^{1, a}$, ${ }^{*}$ Arivaie Rahman ${ }^{2, b}$, Sri Erdawati ${ }^{3, c}$ \\ ${ }^{1}$ Universitas Muhammadiyah, Ponorogo, Jawa Timur, Indonesia \\ ${ }^{2}$ STIT Al-Kifayah Riau, Indonesia \\ ${ }^{3}$ STAI Auliaurrasyidin, Tembilahan, Indragiri Hilir, Riau, Indonesia

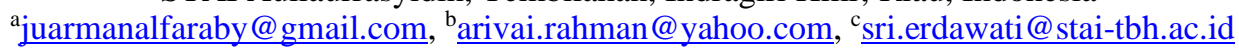

\begin{abstract}
:
This article discussed educators from the perspective of the Al-Quran and Islamic education. Educators are an important element in the Islamic education system. Educators are determinants of the intellectual and moral success of students. So it is interesting to ask how educators in the perspective of the Al-Quran and Islamic education. To answer these research questions, this study used library research and descriptive-analysis methods. The results of this study revealed that the subject of educators according to the Al-Quran is very diverse and forms a hierarchy, Allah, Rasulullah, parents, and teachers. Whereas the predicate that is usually carried by an educator in the Islamic education tradition is Ustadz, Mu'allim, Mursyid, Murabbi, Mudarris, and Mu'addib. Each of these names has almost the same meaning but has its own definitions and characteristics.
\end{abstract}

Keywords: Educator, Al-Quran, Islamic Education

\begin{abstract}
Abstrak:
Artikel ini membincangkan tentang pendidik dalam perspektif Al-Quran dan Pendidikan Islam. Pendidik merupakan satu elemen penting dalam sistem pendidikan Islam. Pendidik menjadi penentu keberhasilan intelektual dan moral peserta didik. Maka menarik untuk mengajukan pertanyaan bagaimana pendidik dalam perspektif Al-Quran dan Pendidikan Islam. Untuk menjawab pertanyaan penelitian tersebut, penelitian ini menggunakan jenis penelitian pustaka (library research) dan metode deskriptif-analisis untuk menjawabnya. Hasil dari penelitian ini menunjukkan bahwa subjek pendidik menurut Al-Quran sangat beragam dan berbentuk hierarki, Allah, Rasulullah, Orang tua, dan Guru. Sedangkan predikat yang biasa disandang oleh seorang pendidik dalam tradisi pendidikan Islam adalah Ustadz, Mu'allim, Mursyid, Murabbi, Mudarris, dan Mu'addib. Masing-masing predikat tersebut memiliki makna yang hampir serupa, namun memiliki pengertian dan ciri khas tersendiri.
\end{abstract}

Kata Kunci: Pendidik, Al-Quran, Pendidikan Islam.

\section{Cara mensitasi artikel ini:}

Juarman, J., Rahman, A., \& Erdawati, S. (2021). Pendidik dalam perspektif Al-Quran dan pendidikan Islam. Mitra PGMI: Jurnal Kependidikan MI, 7(1), 10-24. https://doi.org/10.46963/mpgmi.v7i1.204.

\section{INFORMASI ARTIKEL}

*Corresponding author:

arivai.rahman@yahoo.com

DOI:

https://doi.org/10.46963/mpgmi.v7i1.204

\section{Histori Artikel:}

Diterima $\quad: 27 / 10 / 2020$

Direvisi $\quad: 27 / 12 / 2020$

Diterbitkan $\quad: 25 / 01 / 2021$

\section{PENDAHULUAN}

Seorang pendidik selain fungsinya sebagai Transfer of Knowledge, ia juga merupakan kunci utama dalam membentuk karakter peserta didik. Perannya sebagai pendidik tidak hanya sebatas mengajar di dalam kelas, tetapi juga memberikan binaan dan teladan terhadap peserta didik. Sebab, pada hakikatnya, pendidikan itu adalah "memanusiakan manusia", artinya menjadikan manusia memiliki pengetahuan dan moral dalam melakukan seluruh aktivitas kehidupan. Tujuan pendidikan itu baru akan tercapai 
apabila seorang pendidik yang melakukan tugas dan fungsinya sebagai pendidik dengan maksimal.

Pendidik dalam pandangan umum di masyarakat Islam kerap dikaitkan dengan sosok seorang guru. Pandangan ini dapat dianggap benar, tetapi belum lengkap sepenuhnya. Sebab, Al-Quran tidak pernah membatasi subjek pendidik hanya pada satu subjek ini. Bahkan ajaran Al-Quran sejak awal mengisyaratkan bahwa Allah-lah sebagai pendidik pertama. Sebagaimana wahyu Allah yang pertama kali turun berupa perintah membaca. Maka peran dan subjek Allah sebagai pendidik sangat fundamental. Begitu pula dengan Rasulullah, sebagai utusan-Nya. Ia menjadi pembawa risalah sekaligus contoh aktor keteladanan yang mengaplikasikan dan mengimplementasikan Al-Quran dalam kehidupan.

Setelah itu, ada orang tua sebagai subjek pendidik. Orang tua menjadi subjek pendidik dikarenakan mereka memiliki hubungan biologis dan psikologis yang kuat dengan anak-anaknya. Serta orang tua pula yang memberikan didikan dan pengajaran pertama bagi anak-anaknya. Maka wajar bila posisinya ditempatkan setelah kedudukan Allah dan Rasulullah. Sementara subjek guru sebagai pendidik dalam pengertian yang formal baru berlangsung setelah anak telah memasuki usia sekolah dan menuntut ilmu di lembaga pendidikan tertentu. Subjek-subjek ini amat menarik untuk dibahas pada penelitian ini. Sehingga berhak diajukan pertanyaan bagaimana pendidik menurut AlQuran?

Kekeliruan menempatkan predikat yang dilekatkan kepada seorang pendidik juga mengalami kekeliruan yang patut diluruskan pada penelitian ini. Masyarakat Muslim cenderung menyamaratakan semua pendidik sebagai Ustadz. Padahal, ada banyak sekali predikat yang disematkan oleh dunia pendidik Islam kepada sosok seorang pendidik. Misalnya Mu'allim, Mursyid, Murabbi, Mudarris, dan Mu'addib. Istilah-istilah ini menarik untuk diungkap. Meski kedudukannya sama sebagai pendidik, tetapi masingmasingnya memiliki perbedaan tersendiri yang tidak boleh disamakan. Oleh karena itu, maka penelitian ini berupaya menjelaskan tentang bagaimana predikat pendidik menurut perspektif pendidikan Islam.

Penelitian yang menjadikan pendidik sebagai objek dan variabel penelitian telah banyak dilakukan oleh para sarjana, misalnya oleh Heru Juabdin Sada (Sada, 2015) dan Abduddin Nata (Nata, 2016), keduanya menulis tentang pendidik menurut perspektif AlQuran dan tafsir tematik. Sedangkan Marfuah (Marpuah, 2017) melakukan penelitian yang lebih khusus lagi yakni kriteria pendidik yang terdapat dalam surah Al-Mudatsir: 17, kemudian dikupas dengan merujuk ke beberapa kitab tafsir Al-Quran.

Sementara penelitian tentang pendidik menurut perspektif pendidikan Islam dan atau filsafat pendidikan Islam diteliti oleh Siti Suwaibatul Aslamiyah (Aslamiyah, 2013), Muhammad Ali (Ali, 2017), dan Maisyarah (Maisyaroh, 2019). Sedangkan Ali Maulida (Maulida, 2018), meneliti tentang pendidik menurut pandangan tokoh Muhammad Natsir. 
Hasilnya, menurut Natsir, pendidik harus memiliki tiga kompetensi, yaitu pembinaan mental, persiapan ilmiah, dan kepedulian pada aspek akhlak (Maulida, 2018).

Setelah menguraikan latar belakang dan mengulas penelitian-penelitian yang memiliki relevansi dengan penelitian ini, maka artikel penelitian ini sangat berbeda dengan penelitian sebelumnya. Sebab, penelitian ini tidak dibatasi pada satu perspektif saja, tetapi berupaya menggabungkan dua perspektif, perspektif Al-Quran dan perspektif pendidikan Islam untuk mengeksplorasi pendidik.

\section{METODE PENELITIAN}

Penelitian ini merupakan jenis penelitian pustaka (library research) yang mengandalkan data-data dan teks-teks tertulis yang berkaitan dengan pendidikan Islam sebagai sumber utama penelitian. Sedangkan untuk mengeksplorasi data-data yang terkumpul digunakan metode deskriptif-analisis. Adapun langkah-langkah atau teknik analisis penelitian ini dilakukan dengan beberapa tahapan: Pertama, mengidentifikasi pokok permasalahan yang kemudian diuraikan dalam rumusan masalah (reseacrh question). Kedua, mengumpulkan dan mengategorisasikan data yang sesuai dengan pokok pembahasan. Ketiga, menyajikan data secara deskriptif dan menganalisisnya. Keempat, menarik kesimpulan sesuai dengan rumusan masalah yang telah diajukan.

\section{HASIL DAN PEMBAHASAN}

\section{Subjek Pendidik Menurut Al-Quran}

Menurut isyarat dan petunjuk Al-Quran, setidaknya ada empat subjek pendidik, subjek pendidik pertama adalah Allah Swt., kemudian Rasulullah Saw, kemudian orang tua, dan terakhir Guru (Nata, 1997). Empat subjek pendidik ini akan di uraikan sebagai berikut.

\section{a. Allah SWT sebagai Pendidik}

Al-Quran telah menjelaskan kedudukan Allah Swt sebagai pendidik di dalam banyak ayat, di antaranya pada surah Al-Fatihah [1]:2 yang berbunyi "segala puji bagi Allah Rabb (pendidik) seluruh alam". Sementara dalam surah Al-Nahl [16]: 89 berbunyi "Dan kami turunkan kepadamu Al-Kitab (Al-Quran) untuk menjelaskan segala sesuatu dan petunjuk serta rahmat dan kabar gembira bagi orang-orang yang berserah diri". Dan surah Al-Rahman [55]: 1-4 berbunyi "Tuhan yang maha pemurah, yang telah mengajarkan Al-Quran, dan Dia menciptakan manusia, yang mengajarkannya pandai berbicara".

Berdasarkan ketiga ayat di atas, dapat dipahami bahwa Allah sebagai pendidik bagi manusia dan alam beserta isinya. Sebagai pendidik bagi manusia, Allah memberikan bimbingan kepada manusia secara tidak langsung. Dalam hal ini, Ia mendidik manusia melalui Jibril dengan cara menyampaikan wahyu kepada Nabi Saw untuk disampaikan pula kepada umatnya. Sedangkan sebagai 
pendidik bagi alam semesta, Allah mendidik segala sesuatu yang ada di langit dan bumi yang mencakup seluruh penciptaan dan kekuasaan-Nya.

\section{b. Rasulullah Saw sebagai Pendidik}

Kedudukan Rasulullah sebagai pendidik ditunjuk secara langsung oleh Allah melalui perantara malaikat Jibril sebagai teladan bagi seluruh umat manusia di muka bumi. Hal itu sangat jelas tergambar dalam sebuah Hadits diriwayatkan oleh Ahmad yang berbunyi "sesungguhnya aku diutus kepada manusia hanyalah untuk menyempurnakan akhlak". Hadits ini menunjukkan bahwa Rasulullah dikenal sebagai manusia yang berakhlak mulia dalam potret kehidupannya. Sebagai pendidik, ia telah sukses dalam membina generasigenerasi Islam.

\section{c. Orang Tua sebagai Pendidik}

Sebagai pendidik, orang tua adalah pembimbing di lingkungan keluarga. Orang tua merupakan madrasah pertama bagi pendidikan anak, di mana masa awal kehidupan anak berada ditengah-tengah kedua orang tua yaitu ayah dan ibu. Sebagaimana diungkap oleh Drost, orang tualah yang mengajarkan kepada anak pengetahuan tentang Allah, pengalaman tentang pergaulan manusiawi, dan kewajiban mengembangkan tanggung jawab terhadap diri sendiri maupun terhadap orang lain (Drost, 1998). Sebelum Drost seperti itu, Al-Quran telah menceritakan bagaimana sosok orang tua dalam memberikan pendidikan kepada anaknya, antara lain terdapat dalam surah al-Luqman [31]: 13 yang berbunyi: "Dan ingatlah ketika Luqman berkata kepada anaknya "Hai anakku, janganlah kamu mempersekutukan Allah, karena perbuatan itu merupakan kedzaliman yang amat besar". Ayat ini menurut Quraish Shihab bahwa sosok Luqman yang digambarkan sebagai orang tua mempunyai peran penting dalam mendidik anaknya dengan memberikan nasihat-nasihat yang mencakup pokok agama, yaitu akidah (Shihab, 1994). Dengan demikian, secara tidak langsung proses pendidikan yang diberikan orang tua pertama kali adalah tentang akidah.

Dalam Islam, orang tua merupakan orang yang sangat bertanggung jawab terhadap pendidikan bagi seorang anak. Tanggung jawab tersebut dikarenakan kedua orang tua memiliki hubungan darah dan ikatan kuat terhadap anak yang meliputi dua hal, yaitu: pertama karena kodratnya sebagai orang tua telah ditakdirkan oleh Allah untuk mendidik dan membimbing serta bertanggung jawab bagi kelangsungan hidup anak dari kecil hingga menuju kedewasaan. Kedua karena kepentingan orang tua adalah untuk menjamin kemajuan perkembangan anaknya. Kesuksesan yang dicapai oleh anak sangat tergantung dari peran orang tua dalam mengasuh dan memberikan pendidikan yang terbaik dalam lingkungan keluarga (Tafsir, 1992).

Oleh karena itu, melihat perannya sangat penting dalam menjadikan anak lebih baik, ditambah lagi tanggung jawab yang begitu besar, maka orang tua 
hendaknya mampu dengan sekuat tenaga dalam mendidik agar kelak anaknya tidak terjerumus ke dalam api neraka, sebagaimana dijelaskan dalam Q.S AlTahrim [66]: 6 yang berbunyi "Wahai orang-orang beriman, peliharalah dirimu dan keluargamu dari api neraka". Ayat ini secara eksplisit sangat jelas memberikan perintah kepada orang tua untuk selalu mengingatkan anaknya agar selalu berbuat baik dan menjauhkan dari segala yang menjerumuskan diri ke dalam perbuatan dosa. Ia juga diberikan tanggung jawab besar untuk mendidik anaknya agar tidak tersesat ke jalan sesat yang pada akhirnya menjadikan ia terjerumus ke dalam api neraka.

\section{d. Guru sebagai Pendidik}

Kedudukan seorang guru sebagai pendidik dalam Islam sangat istimewa dan mulia, selain sebagai Transfer of Knowledge. Seorang guru juga tidak bisa dilepaskan dari kewajiban seseorang menuntut ilmu, sebab proses menuntut ilmu tidak lepas dari bimbingan seorang guru. Tanpa guru, seseorang sulit memperoleh ilmu yang baik dan benar. Dalam mengajar dan memberikan bimbingan kepada anak didik, guru dituntut untuk serba bisa dan tahu serta mampu mentransfer pengetahuan kepada anak didiknya sesuai dengan perkembangan potensi yang dimiliki.

Sebagaimana tergambar dalam Al-Quran dalam surah Al-Kahfi [18]: 66-67 yang berbunyi "Musa berkata kepadanya, bolehkah aku mengikutimu agar engkau mengajarkan kepadaku (ilmu yang benar) yang telah diajarkan kepadamu untuk menjadi petunjuk. Dia menjawab, sungguh engkau (Musa) tidak sanggup bersamaku". Ayat ini berkenaan tentang sosok Khidir sebagai pendidik bagi nabi Musa dalam mengajar dan memberi pemahaman yang tidak diketahui oleh Musa (al-Maraghi, 1989). Sebelum mengajarkan ilmu kepada muridnya, tentu Nabi Khidir telah dibekali ilmu yang banyak oleh Allah. Bahkan, Khidir menduga bahwa Musa sebagai muridnya tidak akan sanggup dalam mengikutinya untuk bersabar, karena pada awalnya ia tidak memiliki ilmu.

\section{Predikat Pendidik Menurut Pendidikan Islam}

Pendidik menurut Kamus Besar Bahasa Indonesia (KBBI) diartikan sebagai orang yang profesinya sebagai pengajar (Redaksi, 2005). Istilah ini maknanya sangat luas, mengajar apa saja dapat dikatakan sebagai pendidik baik sebagai guru ngaji, guru silat, maupun guru olahraga. Di dunia pendidikan, umumnya sebutan seorang pendidik identik dengan sebuah jabatan yang disandangnya di sebuah lembaga pendidikan. Sehingga banyak yang mengatakan bahwa pendidik sangat identik dengan guru (Muhadjir, 2000). Tetapi, penyebutan gelar pendidik tidak hanya untuk orang yang memberikan pengetahuan di sebuah lembaga secara formal, tetapi di luar itu dapat dikatakan sebagai pendidik, jika ia memberikan sebuah pengetahuan kepada 
Juarman, Arivaie Rahman, Sri Erdawati

Pendidik dalam Perspektif Al-Quran dan Pendidikan Islam

orang lain. Hal ini menunjukkan bahwa pendidik tidak terlepas atas apa yang ia ajarkan kepada orang lain, baik dalam cakupan formal maupun non-formal.

Dalam konteks pendidikan Islam, pendidik adalah semua pihak yang berusaha memperbaiki orang lain secara Islami, baik dari segi kognitif, afektif maupun psikomotorik. Sebutan untuk pendidik atau guru dalam perspektif pendidikan Islam selalu dikaitkan dengan peran dan intitusi tempatnya mengajar, sehingga lahirlah istilah Ustadz, Mu'allim, Mursyid, Murabbi, Mudarris, dan Mua'addib.

\section{a. Ustadz}

Ustadz merupakan istilah pendidik yang sering digunakan dalam proses kegiatan mengajar di suatu lembaga pendidikan Islam, khususnya pesantren. Gelar ustadz tidak hanya sebatas sebagai pendidik ketika proses pembelajaran berlangsung di dalam kelas, tetapi juga sering digunakan untuk penyebutan orang yang faqih fiddin artinya orang-orang yang benar-benar mengerti dan paham tentang agama (Muhadjir, 2000).

\section{b. Mu'allim}

Istilah mu'allim terdapat didalam surah al-Baqarah [2]: 151, yaitu: "sebagaimana (kami telah menyempurnakan nikmat kami kepadamu) kami telah mengutus kepadamu Rasul diantaramu yang membacakan ayat-ayat kami kepadamu dan mensucikan kamu dan mengajarkan kepadamu Al-Kitab dan AlHikmah, serta mengajarkan kepadamu apa yang belum kamu ketahui". Ayat ini menjelaskan bahwa kata Mu'allim dimaknai sebagai orang yang mampu mengkonstruksikan ilmu pengetahuan secara sistematis dalam pikiran peserta didik, baik berbentuk ide (gagasan), wawasan, kecakapan, dan sebagainya yang ada kaitannya dengan sesuatu. Ramayulis menambahkan kata $\mathrm{Mu}$ 'allim tersebut juga diartikan sebagai orang yang memiliki kemampuan unggul dibandingkan peserta didik, artinya ia mampu menghantarkan peserta didik menjadi lebih baik menuju ke arah kesempurnaan dan kemandirian (Ramayulis, 2009).

\section{c. Mursyid}

Istilah Mursyid berasal dari bahasa Arab,"rasysyada" (mengajar). Mursyid juga mempunyai persamaan makna dengan kata Mu'allim (penunjuk, pemimpin, pengajar, dan instruktur). Dalam bentuk lain, kata tersebut juga diartikan balagha rasydahu(orang yang telah mencapai titik kedewasaan). Secara terminologi, Mursyid merupakan salah satu sebutan pendidik dalam pendidikan Islam, tugasnya membimbing peserta didik supaya mampu menggunakan akal pikiran secara tepat, sehingga mencapai kedewasaan dalam berpikir (Ramayulis, 2009).

\section{d. Murabbi}

Murabbi adalah bentuk dari bahasa Arab, "raba, yarbu" (bertambah dan tumbuh), "rabiya, yarba" (tumbuh dan menjadi besar), dan kata "rabba, yarubbu" (memperbaiki, menguasai, memimpin, menjaga, dan memelihara). Hal 
itu sebagaimana tergambar dalam Al-Quran surah Al-Isra' [19]: 24 yang berbunyi: "dan rendahkanlah dirimu terhadap mereka berdua dengan penuh kesayangan dan ucapkanlah: Wahai Tuhanku, kasihilah mereka keduanya sebagaimana mereka berdua telah mendidik aku sewaktu kecil".

Istilah Murabbi tersebut mengandung makna yang luas, diantaranya a) mendidik dalam rangka meningkatkan kemampuannya, b) memberi bantuan dalam proses mengembangkan potensi yang dimilikinya, c) meningkatkan kemampuan dari kurang dewasa menjadi lebih dewasa baik berhubungan dengan pola pikir, wawasan, ataupun lainnya, d) menghimpun seluruh komponen pendidik yang bisa menyukseskan pendidikan, e) memobilisasi perkembangan dan pertumbuhan peserta didik, f) memperbaiki tingkah laku dari yang buruk menjadi lebih baik, g) memiliki kewenangan, kehormatan, dan kekuasaan terhadap perkembangan kepribadian, dan h) pendidik merupakan orang tua kedua setelah orang tua di rumah yang berhak atas perkembangan dan pertumbuhan anak. Istilah Murrabi ini menunjukkan bahwa seorang pendidik wajib memberikan pendidikan yang terbaik dalam rangka mencapai pertumbuhan dan perkembangan jiwa peserta didik sehingga ia mampu mencapai tujuan pendidikan yang Islami.

\section{e. Mudarris}

Mudarris berasal dari bentuk kata "darrasa" (mengajar atau mendidik). Sementara secara terminologi, Mudarris diartikan orang yang memiliki kepedulian intelektual dan informasi, serta memperbaharui ilmu pengetahuan dan keahliannya secara berkesinambungan, berusaha semampunya membuat peserta didik menjadi cerdas, serta melatih keterampilan sesuai dengan bakat, minat, dan kemampuannya (Muhaimin, 2005a).

\section{f. Mu'addib}

Mu'addib adalah bentuk fi' il madi, dari kata 'addaba (mendidik), sementara $M u$ 'addib diartikan sebagai orang yang mendidik. Bila ditinjau dari segi terminologi, Mu'addib merupakan seorang pendidik yang bertugas untuk menciptakan suasana belajar yang mampu menggerakkan peserta didik berperilaku beradab sesuai dengan norma, tata susila, dan sopan santun yang berlaku dalam masyarakat (Ramayulis, 2009). Dengan demikian, penyebutan istilah pendidik yang telah diuraikan di atas menunjukkan bahwa istilah-istilah tersebut pada hakikatnya menunjukkan satu kesatuan sebagai orang yang memberikan pendidikan atau pengajaran.

Meski memiliki banyak predikat, sebutan, dan istilah yang dilekatkan kepada seorang pendidik, namun pada hakikatnya semua tertuju pada pemberian ilmu pengetahuan. Dalam konteks ini, mereka semua dikatakan sebagai orang-orang yang berusaha dalam memberikan ilmu pengetahuan, mengembangkan ilmu pengetahuan, melakukan pembaharuan, dan menerapkannya dalam kehidupan sehari-hari sehingga 
tercapainya tujuan pendidikan yang berorientasi pada aspek kognitif, afektif, psikomotorik maupun aspek spiritual yang ada pada dirinya. Dengan demikian, penyebutan istilah tersebut hanya berbeda dalam sebutan saja pada intinya sama sebagai pihak yang bertanggung jawab dalam proses memperbaiki diri orang lain.

Kesimpulan di atas, selaras dengan pendapat Abdul Mujib yang mengatakan bahwa pendidik merupakan bapak rohani (spritual father) bagi peserta didik dalam memberikan santapan rohani dengan ilmu, pembinaan akhlak, dan memperbaiki tingkah laku peserta didik yang buruk (Mujib, 2008). Begitu pula pendapat yang dikemukan oleh Ahmad Tafsir, ia memaknai pendidik sebagai orang yang bertanggung jawab dalam pengembangan ilmu pengetahuan peserta didik baik dari segi kognitif, afektif, maupun psikomotorik (Tafsir, 1992).

\section{Kedudukan Pendidik}

Pendidik dalam Islam mempunyai kedudukan yang sangat mulia. Asma Hasan Fahmi menyatakan bahwa kedudukan seorang pendidik dalam Islam berada pada posisi kedua setelah martabat para Nabi (Asma Hasan Fahmi, 1979). Ini dikarenakan sebagai pendidik mempunyai tanggung jawab yang besar dalam memperbaiki akhlak peserta didik sehingga menjadi pribadi yang baik. Sementara Athiyah Al-Abrasy menambahkan seseorang dikatakan berjasa besar apabila ia berilmu dan mengamalkan ilmunya ke jalan yang benar (Abudin Nata, 1997). Seorang pendidik bagaikan matahari yang menyinari orang lain dan menerangi dirinya sendiri. Maka orang yang berprofesi sebagai pendidik termasuk orang mulia dan terhormat, karena ia menebarkan kebaikan kepada orang lain maupun pada dirinya sendiri.

Kedudukan pendidik sebagaimana disinggung sebelumnya sangat istimewa, hal itu tergambar dalam sebuah Hadist yang diriwayatkan oleh Abi Umamah, Rasulullah bersabda "sesungguhnya Allah, para malaikat, dan semua makhluk yang ada dilangit dan bumi, sampai semut yang ada di liangnya dan juga ikan besar, semuanya bersalawat kepada mu'allim yang mengajarkan kebaikan kepada manusia" (alMubarakfuri, 1979a). Hadits ini menjelaskan bahwa pendidik mempunyai kedudukan sangat sentral dan tinggi dalam Islam. Kedudukan tersebut menurut Ahmad Tafsir tidak bisa dipisahkan dari pandangan semula bahwa ilmu pengetahuan bersumber pada Allah, sehingga pada akhirnya kedudukan yang diberikan pada pendidik sangatlah tinggi (Tafsir, 1992).

Al-Ghazali juga pernah menjelaskan tentang kedudukan seorang pendidik yang tidak lepas dari upayanya dalam menyempurnakan, memperbaiki, membersihkan, dan mengarahkan orang lain agar dekat kepada Allah, karena mengajarkan suatu ilmu itu merupakan tugasnya sebagai pendidik (Sulaiman, 1990). Oleh karena itu, kedudukan yang istimewa diberikan kepada pendidik ternyata seimbang dan sesuai dengan tugas dan tanggung jawabnya yang berat. Kedudukan yang diberikan tersebut akan berimplikasi terhadap peran pendidik dalam mewujudkan tujuan pendidikan Islam yang tidak lain mengembangkan seluruh potensi peserta didik agar menjadi 
muslim yang sempurna (Langgulung, 1991). Jadi, pencapaian tujuan pendidikan tersebut tidak lepas dari upaya pendidik dalam menjalankan tugasnya dengan sungguh-sungguh dan konsisten.

\section{Peran Pendidik}

Peran merupakan konsep yang tidak bisa dilepaskan dari sebuah status, kedudukan, dan posisi seseorang. Veitzhal Rivai berpendapat bahwa peran adalah suatu bentuk perilaku yang diatur dan diharapkan dari seseorang dalam posisi tertentu (Rivai, 2004). Dalam dunia pendidikan, seorang pendidik tentu memiliki peran sesuai dengan kedudukan atau posisinya. Menurut Syaiful Akhyar, secara garis besar seorang pendidik mempunyai peran sebagai ukuran kognitif, agen moral, inovator, dan kooperatif (Lubis, 2006). Peran tersebut sebagaimana dijabarkan berikut:

a. Pendidik sebagai ukuran kognitif, pendidik berperan dalam mewariskan pengetahuan kepada peserta didik yang berupa keterampilan yang sesuai dengan ukuran kemampuan yang dimiliki.

b. Pendidik sebagai agen moral, pendidik berperan dalam upaya mendidik warga masyarakat agar bisa membaca dan menulis, pandai berhitung, dan mampu melakukan keterampilan kognitif lainnya.

c. Pendidik sebagai inovator, pendidik harus mampu berperan dalam melakukan inovasi-inovasi baru di dunia pendidikan.

d. Pendidik sebagai kooperatif, pendidik harus melaksanakan tugasnya secara bekerja sama antara para pendidik satu dengan lainnya. Dengan demikian, sebagai pendidik ia harus mampu melaksanakan seluruh tugas yang berkaitan dengan kewajibannya baik dalam mengembangkan kognitif, mendidik masyarakat menjadi terampil, melakukan inovasi baru, maupun melakukan tugas secara bersama-sama.

Jika ditinjau dari pendidikan Islam, maka peran pendidik adalah sebagai bapak rohani atau bapak spiritual dalam rangka memberikan santapan jiwa (rohani) dengan ilmu dan pendidikan akhlak kepada peserta didik serta mampu memperbaiki tingkah laku yang ada (Suyudi, 2014). Peran ini bertujuan agar pendidik menjalankan fungsinya dalam mentransfer ilmu pengetahuan dan mentransformasi nilai-nilai atau norma-norma yang ada sehingga terciptalah pribadi yang baik.

Mengingat peram pendidik yang sangat signifikan dalam menyiapkan generasi mendatang, maka seorang pendidik wajib dimuliakan. Sebagaimana ungkapan Athiyah Al-Abrasyi "menghormati pendidik berarti menghormati anaknya", artinya suatu bangsa yang ingin maju peradabannya adalah bangsa yang mampu menghargai dan menghormati sosok seorang pendidik (Uhbiyati, 1997). Maka, peran pendidik sangatlah besar, karena ia tidak hanya memberikan ilmu pengetahuan, tetapi juga harus mampu membina peserta didik agar menjadi beradab dan bermoral. 


\section{Kode Etik Pendidik}

Kode etik dalam profesi kependidikan merupakan kontrol dari seluruh aktivitas kependidikan, ia juga berperan dalam menjunjung tinggi martabat pendidik, menyejahterakan anggota, meningkatkan pengabdian para anggota pendidik, meningkatkan mutu pendidik, maupun meningkatkan mutu organisasi pendidik. Demi tercapai seluruh aktivitas kependidikan di atas, diharapkan pendidik bisa bekerja secara optimal terutama dalam meningkatkan budi pekerti agar dapat mengembalikan wibawa lembaga dan tenaga kependidikan (Subagyo, 2002). Setiap orang yang berprofesi sebagai pendidik akan selalu berpegang pada kode etik pendidik atau guru agar dapat terhindar dari segala bentuk penyimpangan. Maka dalam menjalankan tugasnya sebagai pendidik, ia diwajibkan mematuhi dan terikat dengan kode etik yang ada.

Dalam Islam, kode etik tidak bisa dilepaskan dari seorang pendidik ketika memberikan bimbingan dan pendidikan kepada peserta didik. Ia juga sebagai sarana dalam mengatur norma-norma yang mengikat tingkah laku peserta didik. Menurut Al-Kanani, kode etik pendidik dalam menjalankan tugas dan tanggung jawab sebagai pendidik dibagi menjadi tiga macam, yaitu:

a. Kode etik yang berhubungan dengan dirinya sendiri seperti pendidik hendaknya insaf terhadap pengawasan Allah, memelihara kemuliaan ilmu, zuhud, tidak berorientasi pada dunia, menjauhkan diri dari segala fitnah.

b. Kode etik yang berhubungan dengan pelajaran seperti suci dari hadats sebelum mengajar, berdoa terlebih dahulu sebelum keluar rumah, mengambil tempat yang dapat terlihat murid, mulai mengajar dengan membaca ayat Al-Quran, menjaga ketertiban majelis, menegur peserta didik yang tidak sopan santun, bersikap bijaksana dalam melakukan pembahasan, penyampaian pelajaran, dan menjawab pertanyaan, mengatur volume agar tidak terlalu keras dan tidak terlalu pelan, menutup pelajaran dengan menunjukkan keikhlasan, tidak memberikan pelajaran yang tidak dikuasainya.

c. Kode etik ketika berada di tengah para peserta didik seperti mengajar dengan niat keridhoan Allah, tidak menolak peserta didik yang mempunyai niat tulus dalam belajar, mencintai peserta didik sebagaimana mencintai dirinya sendiri, motivasi, menggunakan bahasa yang dipahami oleh peserta didik, melakukan evaluasi terhadap kegiatan belajar mengajar, dan bersikap adil (Sada, 2015).

Mengacu pada kode etik di atas, maka seorang pendidik dalam Islam harus memahami aturan-aturan yang telah berlaku. Sehingga perannya sebagai pendidik tidak menyimpang, seperti menghukum peserta didik secara berlebihan, memukulnya dengan keras, memberikan pelajaran yang tidak sesuai dengan tema pelajaran, menggunakan bahasa yang sulit dipahami, dan tidak bersikap adil terhadap para peserta didiknya. Hal itu dilakukan agar proses belajar mengajar berjalan dengan efektif dan efisien serta sesuai dengan tujuan pendidikan Islam. 


\section{Syarat dan Sifat Pendidik}

Mengingat tugas dan tanggung jawabnya yang sangat berat dalam Islam, tentu tidak semua orang bisa menjadi seorang pendidik yang baik. Mereka harus dibekali dan wajib memenuhi persyaratan yang ada. Syarat tersebut sebagaimana diungkapkan oleh Al-Kanani yaitu: a) pendidik harus insaf dengan peringatan Allah terhadap segala perkataan, perbuatan yang menjadi amanah harus dipegang olehnya. b) pendidik hendaknya memelihara kemuliaan peserta didik. c) pendidik harus bersifat zuhud. d) tidak berorientasi duniawi dengan menjadikan ilmu sebagai alat mencapai kedudukan atas orang lain. e) pendidik harus menjauhi mata pencaharian yang hina dalam pandangan syara' dan sesuatu yang mendatangkan fitnah terhadap dirinya. f) pendidik hendaknya memelihara syiar-syiar Islam. g) pendidik hendaknya rajin dalam melakukan kegiatan yang disunahkan oleh agama baik dalam lisan maupun perbuatan. $\mathrm{h}$ ) pendidik harus memelihara akhlak yang berupa memuliakan pergaulannya dengan orang lain. i) pendidik hendaknya mengisi waktu luangnya dengan hal yang bermanfaat. j) hendaknya sebagai pendidik harus selalu belajar dan tidak merasa malu untuk menerima ilmu dari orang yang rendah darinya. $\mathrm{k}$ ) pendidik hendaknya rajin meneliti, menyusun, dan mengarang dengan memperhatikan keterampilan dan keahlian yang dibutuhkan (Ramayulis, 2005).

Sementara Persyaratan yang dimiliki oleh pendidik di atas dapat terlengkapi dengan baik, apabila seorang pendidik memiliki sifat-sifat yang mengikutinya. Sifatsifat tersebut sebagaimana diungkapkan oleh Imam Al-Ghazali dalam kitabnya Ihya' Ulumuddin meliputi: a) lemah lembut, b) tidak mengharapkan upah, pujian, ucapan terima kasih dan balas jasa, c) jujur dan terpercaya, d) membimbing dengan kasih sayang, e) berbudi luhur dan toleransi, f) tidak merendahkan ilmu lain, g) memperhatikan perbedaan individu, dan h) konsisten (al-Ghazali, 1996).

Al-Nahlawi juga menambahkan bahwa sebagai pendidik harus bersifat Rabbani (yaitu segala aktivitas yang berhubungan dengan gerak, niat, dan ucapan sejalan dengan nilai-nilai Islam), ikhlas, penyabar, jujur, selalu meningkatkan ilmu dan mengkajinya, menguasai berbagai metode dalam mengajar, mampu mengelola murid, memahami perkembangan psikis anak, tanggap terhadap berbagai kondisi yang mempengaruhi jiwa dan pola pikir, dan mampu bersikap adil (al-Nahlawi, 1996). Sementara Asma Hasan Fahmi berpendapat, ada beberapa kriteria sifat yang harus dimiliki seorang pendidik, diantaranya: a) tidak menerima upah, karena semata hanya berharap ridho' Allah. b) seorang pendidik harus terlebih dahulu membersihkan anggota badan dari dosa. c) harus sesuai antara perkataan dan perbuatan. d) rendah hati. e) harus sabar, hormat, lemah lembut, dan kasih sayang, serta tabah untuk mencapai suatu keinginan (Fahmi, 1979).

Sifat-sifat pendidik sebagaimana telah disebutkan oleh beberapa tokoh di atas, merupakan sifat yang sangat ideal bagi seorang pendidik dalam memberikan ilmu pengetahuan kepada peserta didik. Agar sifat-sifat di atas tercapai maka pendidik 
harus memiliki kemauan yang keras. Seorang pendidik tidak hanya duduk santai, akan tetapi selalu melakukan usaha semaksimal mungkin agar apa yang menjadi kewajiban tersebut dapat terpenuhi dengan baik sehingga dalam penerapannya di lapangan sesuai dengan harapan dan tujuan pendidikan Islam.

\section{Tugas dan Hak Pendidik}

Para ahli pendidikan Islam dan Barat sepakat bahwa tugas seorang pendidik adalah mendidik. Mendidik tidak hanya sebatas mengajar, memberi dorongan, memuji, menghukum, memberi teladan, membiasakan dan lain sebagainya. Akan tetapi, mendidik mencakup seluruh tugas yang amat luas (H. H. Ihsan \& Ihsan, 2001). Undang-Undang No. 20 tahun 2003 tentang Sisdiknas menyatakan bahwa tugas pendidik adalah sebagai perencana, pelaksana proses pembelajaran, menilai hasil pembelajaran, melakukan pembimbingan, pelatihan, penelitian, dan pengabdian kepada masyarakat (Depdiknas, 2009) Melalui Undang-Undang tersebut, penulis berupaya menjabarkan bahwa tugas pendidikan antara lain: a) organisator; sebagai pengelola dan perencana seluruh aktivitas pembelajaran seperti penyusunan seperangkat pembelajaran, b) Instruktur; mampu menyampaikan pembelajaran kepada peserta didik di dalam kelas, c) evaluator; melakukan evaluasi hasil pembelajaran yang ada pada peserta didik dalam kesehariannya, dan d) Inspirator; senantiasa memberikan masukan atau ide maupun arahan dalam menyelesaikan problem pembelajaran.

Buya Hamka diikuti oleh Dzakiah Drajat mengatakan bahwa tugas pendidik utamanya adalah membantu, mengembangkan kemampuan peserta didik untuk mendapatkan pengetahuan yang luas dilandasi akhlak mulia, dan menjaga komunikasi dengan peserta didik (Ramayulis \& Nizar, 2010). Sementara di dalam Al-Quran telah dijelaskan tugas seorang pendidik sebagaimana tergambar dalam surah Ali Imran [3]: 79. Dalam ayat tersebut diisyaratkan bahwa tugas terpenting Rasulullah sebagai pendidik adalah mengajarkan al-Kitab, hikmah dan penyucian diri sebagaimana telah diperintahkan oleh Allah sehingga menjadi tuntunan dan pedoman bagi manusia dalam menjalankan kehidupan di dunia dan akhirat.

Tugas pendidik sebagaimana disebutkan dalam Al-Quran di atas hanya berlaku bagi Rasulullah, karena ia menerima wahyu dalam mengajarkan Al-Kitab kepada umatnya. Sementara itu, jika ditinjau dari pendidikan Islam, maka tugas pendidik yaitu: a) membimbing dan mengenal orang yang dididik tentang pribadi, kebutuhan, kesanggupan, bakat, dan minatnya. b) menciptakan situasi dan keadaan agar tindakan pendidikan dapat berlangsung dengan baik, dan mendapatkan hasil yang memuaskan. c) dan memiliki pengetahuan yang diperlukan, pengetahuan tersebut tidak hanya diketahui, tetapi diamalkan dan diyakini sendiri (Ramayulis \& Nizar, 2010). Sehingga seorang pendidik berhasil dalam melaksanakan tugasnya bila telah mampu menjalankan ketiga tugas tersebut secara maksimal. 
Terlepas dari tugas dan tanggung jawab yang diemban oleh seorang pendidik, mereka juga berhak menerima hak yang menjadi balas jasa atas tugas yang diembannya.

a. Hak penghormatan, sebagai orang yang bertanggung jawab terhadap perkembangan jasmani dan rohani peserta didik agar mencapai tingkat kedewasaan, maka sudah selayaknya seorang pendidik diberikan penghormatan. Salah satu bentuk penghormatan terhadap seorang pendidik adalah dengan memuliakannya, karena tanpa peran pendidik peradaban yang carah tidak akan terwujud.

b. Hak menerima gaji, masalah penerimaan gaji bagi pendidik masih menjadi polemik yang diperdebatkan oleh para ulama. Sebagian ulama ada yang membolehkan, sedangkan yang lain ada yang melarang menerima gaji. AlQobisi membolehkan seorang pendidik dalam menerima gaji dari hasil mengajar ilmu Al-Quran dan ilmu-ilmu lainnya (Ramayulis \& Nizar, 2010). Sementara alGhazali dan Asma Hasan Fahmi berpendapat bahwa seorang pendidik tidak boleh menerima gaji dari hasil mengajar, karena mendidik itu semata-mata hanya ingin mengharapkan keridhoan dari Allah (M Suyudi, 2014). Menurut penulis tentang penerimaan gaji profesi mengajar boleh saja diterima, karena pada dasarnya mendidik merupakan pekerjaan dan seorang pendidik memerlukan biaya untuk memenuhi kebutuhan hidupnya. Sedangkan niatnya memang mesti benar-benar ikhlas untuk mencari keridhoan Allah.

\section{KESIMPULAN DAN SARAN}

Pendidik merupakan elemen terpenting dalam sistem pendidikan Islam. Sebab karena pendidiklah anak-anak didik menjadi manusia yang sukses secara moral dan intelektual. Subjek pendidik dalam perspektif Al-Quran sangat beragam dan membentuk hierarki. Aktor pendidik yang paling pertama adalah Allah Swt, karena Dia-lah yang menciptakan dan mengatur alam semesta ini, termasuk mengajari manusia melalui perantara malaikat Jibril. Aktor kedua adalah Rasulullah Saw, sebab ialah yang menerima didikan dan pengajaran berupa wahyu dari Allah. Ketiga, orang tua, aktor ini disebabkan oleh hubungan biologis dan psikologis antara orang tua dan anaknya. Keempat, guru, guru sebagai pentransfer pengetahuan baik di lembaga formal maupun non-formal. Sedangkan menurut kacamata pendidikan Islam, pendidik memiliki banyak sebutan atau julukan. Setidaknya terdapat enam predikat yang lumrah dilekatkan kepada seorang pendidik, yaitu: Ustadz, Mu'allim, Mursyid, Murabbi, Mudarris, dan Mu'addib. Predikat-predikat tersebut sangat mirip, namun memiliki perbedaan secara definitif dan kekhususan pemaknaan tersendiri. 
Juarman, Arivaie Rahman, Sri Erdawati

Pendidik dalam Perspektif Al-Quran dan Pendidikan Islam

\section{REFERENSI}

Ali, M. (2017). Hakikat Pendidik Dalam Pendidikan Islam. Tarbawiyah: Jurnal Ilmiah Pendidikan, 11(01), 82-97. Retrieved from https://ejournal.metrouniv.ac.id/index.php/tarbawiyah/article/view/361.

Aslamiyah, S. (2013). Pendidik dalam perspektif pendidikan Islam. Al Hikmah: Jurnal Studi Keislaman, 3(2), 2. https://doi.org/10.36835/hjsk.v3i2.371.

Depdiknas. (2009). Kurikulum Tingkat Satuan Pendidikan. Jakarta: Pusat Kurikulum Balitbang Depdiknas.

Drost, J.I.G.M. (2008). Sekolah: Mengajar atau Mendidik? Yogyakarta: Kanasius.

Fahmi, A. H. (1979). Sejarah dan Filsafat Pendidikan Islam. Jakarta: Bulan Bintang.

al-Ghazali. (1996). Ihya' Ulum al-Din. Kairo: Dar Al-Ihya Al-Kutub Al-Arabiyah.

Ihsan, A. H., \& Ihsan, F. (2001). Filsafat Pendidikan Islam. Bandung: Pustaka Setia.

Langgulung, H. (1991). Kreativitas dan Pendidikan Islam: Analisis Psikologi dan Falsafah. Jakarta: Pustaka Al-Husna.

Lubis, S. A. (2006). Dasar-Dasar Kependidikan. Bandung: Cita Pustaka Media.

Maisyaroh, M. (2019). Hakikat Pendidik dalam Perspektif Falsafah Pendidikan Islami. Jurnal Pendidikan Agama Islam Al-Thariqah, 4(2), 1-9. https://doi.org/10.25299/al-thariqah.2019.vol4(2).4079.

Al-Maraghi, A. M. (1989). Tafsir Al-Maraghi. Bairut: Dar al-Fiqh.

Marpuah, M. (2017). Kriteria Pendidikan dalam Sudut Pandang al-Qur'an Surat alMuddatstir Ayat 1-7. Syntax Literate; Jurnal Ilmiah Indonesia, 2(11), 91-105. Retrieved from http://jurnal.syntaxliterate.co.id/index.php/syntaxliterate/article/view/260.

Maulida, A. (2018). Kompetensi Pendidik Dalam Perspektif M. Natsir (Studi Analitis Pemikiran Pendidikan M. Natsir dalam "Fiqhud Dakwah"). Al-Fikri: Jurnal Studi Dan Penelitian Pendidikan Islam, 1(2), 39-46. http://dx.doi.org/10.30659/jspi.v1i2.3207.

Al-Mubarakfuri. (1979). Tuhfah Al-Ahwadzi Syarh Jami' al-Tirmidzi. Bairut: Dar al-Fikr.

Muhadjir, N. (2000). Ilmu pendidikan dan perubahan sosial. Yogyakarta: Rake Sarasin.

Muhaimin. (2005). Pengembangan Kurikulum Pendidikan Agama Islam di Sekolah, Madrasah, dan Perguruan Tinggi. Jakarta: Raja Grafindo Perkasa.

Muhajir, A. (2000). Ilmu Pendidikan dan Perubahan Sosial: Teori Pendidikan Pelaku Sosial Kreatif. Yogyakarta: Rake Sarasin.

Mujib, A. (2008). Ilmu Pendidikan Islam. Jakarta: Kencana Prenada Media.

Al-Nahlawi. (1996). Usul Al-Tarbiyah al-Islamiyah Wa Asalibuha Fi al-Bait Wa alMadrasah Wa al-Mujtama’. Bairut: Dar al-Fikr.

Nata, Abudin. (1997). Filsafat Pendidikan Islam I (1st ed.). Jakarta: Logos Wacana Ilmu.

23 Print - ISSN: 2443-0021

Online - ISSN: 2716-4136 
Nata, Abudin. (2016). Pendidikan dalam Perspektif Al-Qur'an. Jakarta: Prenada Media.

Ramayulis. (2005). Metodologi Pendidikan Agama. Jakarta: Kalam Mulia.

Ramayulis. (2009). Filsafat Pendidikan Islam. Jakarta: Kalam Mulia.

Ramayulis, \& Nizar. (2010). Filsafat Pendidikan Islam. Jakarta: Kalam Mulia.

Rivai, V. (2004). Manajemen Sumber Daya Manusia untuk Perusahaan. Jakarta: Raja Grafindo Perkasa.

Sada, H. J. (2015). Pendidik Dalam Perspektif Al-Qur'an. Al-Tadzkiyyah, 6(1), 93-105.

Shihab, M. Q. (1994). Studi Kritis Tafsir Al-Manar. Bandung: Pustaka Hidayah.

Subagyo. (2002). Pendidikan Kewarganegaraan III. Semarang: IKIP Semarang Press.

Sulaiman, F.H. (1990). Pemikiran Pendidikan tentang Al-Ghazali. Yogyakarta: Pustaka Pelajar.

Suyudi, M. (2014). Filsafat Pendidikan Islam: Kajian filosofis dan pemikiran pendidikan Islam.

Tafsir, A. (1992). Ilmu pendidikan dalam perspektif Islam. Remaja Rosdakarya.

Tim Redaksi. (2005). Kamus Besar Bahasa Indonesia. Jakarta: Balai Pustaka.

Uhbiyati, N. (1997). Ilmu Pendidikan Islam I. Bandung: Pustaka Setia. 